\title{
Een verklaring van de beroepenstructuur van bedrijfstakken
}

Citation for published version (APA):

Dekker, R., de Grip, A., \& Heijke, J. A. M. (1988). Een verklaring van de beroepenstructuur van bedrijfstakken. Researchcentrum voor Onderwijs en Arbeidsmarkt, Faculteit der Economische Wetenschappen. ROA Working Papers No. 2 https://doi.org/10.26481/umarow.1988002

Document status and date:

Published: 01/01/1988

DOI:

10.26481/umarow.1988002

Document Version:

Publisher's PDF, also known as Version of record

\section{Please check the document version of this publication:}

- A submitted manuscript is the version of the article upon submission and before peer-review. There can be important differences between the submitted version and the official published version of record.

People interested in the research are advised to contact the author for the final version of the publication, or visit the DOI to the publisher's website.

- The final author version and the galley proof are versions of the publication after peer review.

- The final published version features the final layout of the paper including the volume, issue and page numbers.

Link to publication

\footnotetext{
General rights rights.

- You may freely distribute the URL identifying the publication in the public portal. please follow below link for the End User Agreement:

www.umlib.nl/taverne-license

Take down policy

If you believe that this document breaches copyright please contact us at:

repository@maastrichtuniversity.nl

providing details and we will investigate your claim.
}

Copyright and moral rights for the publications made accessible in the public portal are retained by the authors and/or other copyright owners and it is a condition of accessing publications that users recognise and abide by the legal requirements associated with these

- Users may download and print one copy of any publication from the public portal for the purpose of private study or research.

- You may not further distribute the material or use it for any profit-making activity or commercial gain

If the publication is distributed under the terms of Article $25 \mathrm{fa}$ of the Dutch Copyright Act, indicated by the "Taverne" license above, 


\title{
EEN VERKLARING VAN DE BEROEPENSTRUCTUUR VAN BEDRIJFSTAKKEN
}

ROA-W-1988/2

\author{
R.J.P. Dekker, A. de Grip, J.A.M. Heijke
}

RESEARCHCENTRUM VOOR ONDERWIJS EN ARBEIDSMARKT

Faculteit der Economische Wetenschappen

Rijksuniversiteit Limburg

Maastricht, oktober 1988 
INHOUDSOPGAVE

Bladzijde

SAMENVATTING

VERANTWOORDING

$\mathbf{i} \mathbf{i}$

1. INLEIDING

2. HET BEROEPENMODEL

2.1. Inleiding

2.2. Mogelijke factoren voor de ontwikkeling van de beroepenstructuur

2.3. Specificering van de verklarende variabelen

3. DE ECONOMETRISCHE MODELLERING

10

3.1. Afleiding van de te schatten vergelijking 10

3.2. Modelkeuze

4. SCHATTINGSRESULTATEN 16

4.1. Globale resultaten 16

4.2. Bespreking van de resultaten op beroepssector niveau

BIJLAGE I : Overzicht van de beroepencodes en de bijbehorende benaming

BIJLAGE II : Bedrijfstakindeling en bronvermelding van de variabelen

BIJLAGE III: Verschillen tussen gecorrigeerde $R^{2}$ voor het gekozen model en het bedrijfstakdummy model

BIJLAGE $V$ : Schattingsresultaten 
SAMENVATTING

In deze studie wordt gepoogd de oorzaken van de ontwikkeling van de beroepenstructuur in beeld te brengen. Het onderzoek vormt een schakel in de constructie van het informatiesysteem onderwijs-arbeidsmarkt, zoals dat door het ROA wordt ontwikkeld. Als uitgangspunt worden de beroepsklasse-aandelen per bedrijfstak genomen. De verklarende variabelen zijn de technologische ontwikkeling en conjuncturele en structurele bedrijfstakontwikkelingen. Per beroepsklasse vindt een schatting plaats aan de hand van een lineair model, waarbij de gewogen kleinste kwadraten (Weighted Least Squares) methode wordt toegepast. Om meerdere variabelen in de vergelijking te kunnen opnemen zijn de data gepoold over de bedrijfstakken en de tijd. In $40 \%$ van de gevallen wordt gekozen voor een model waarin verklarende variabelen zijn opgenomen, in de overige gevalien volstaat een sectordummy-model. 


\section{VERANTWOORDING}

Deze studie is uitgevoerd binnen het kader van een meerjarige onderzoeksopdracht van het Ministerie van Onderwijs en Wetenschappen. De opdracht betreft de ontwikkeling van een informatiesysteem onderwijs-arbeidsmarkt, dat bruikbaar is voor de school- en beroepskeuze van leerlingen in het voortgezet en hoger onderwijs (ROA 1988).

Het hier gepresenteerde onderzoek is een tussenstap in de constructie van het informatiesysteem onderwijs-arbeidsmarkt. Het is gericht op de uitbouw en verbetering van het beroepenmodel. In een latere fase zal aandacht worden geschonken aan de modellering van de opleidingenstructuur.

Het onderzoek stond onder leiding van prof. dr. J.A.M. Heijke, directeur van het ROA. Het onderzoek werd uitgevoerd door drs. R.J.P. Dekker, waarbij een voortdurende terugkoppeling plaatsvond met dr. A. de Grip. Verder gaat dank uit naar drs. L.F.M. Groot voor zijn bijdrage tijdens de besprekingen. De student-assistenten $G$. Kloek en $M_{0} H_{0}$. Wieling waren behulpzaam bij de dataverzameling en de verwerking van de schattingsresultaten. 


\section{INLEIDING}

In dit rapport wordt verslag gedaan van de constructie van een verklarend model waarin gepoogd is per beroep het werkgelegenheidsaandeel in de verschillende bedrijfstakken te verklaren. Het model is bedoeld als een aanzet om in een later stadium tot prognoses van de werkgelegenheid naar beroep op de middellange termijn te kunnen komen. Deze prognoses vormen een belangrijke schakel in het informatiesysteem onderwijs-arbeidsmarkt dat door het ROA wordt ontwikkeld ${ }^{1}$. In dit rapport ligt de nadruk op het ontwikkelen van een verklarend model en is alleen gekeken naar de beroepenstructuur. In een latere fase van de constructie van het informatiesysteem zal op soortgelijke wijze worden geprobeerd een model te ontwikkelen met betrekking tot de opleidingenstructuur van de verschillende beroepen.

Informatie omtrent de werkgelegenheidsontwikkeling op de middellange termijn in de verschillende beroepscategorieën kan wellicht bijdragen tot een betere aansluiting van het onderwijs op de arbeidsmarktbehoeften. Degenen die voor hun studiekeuze staan, wordt de mogelijkheid geboden rekening te houden met de verwachtingen ten aanzien van de werkgelegenheidsperspectieven van de verschillende beroepen op het moment warop zij zullen afstuderen.

In de Verenigde Staten geeft het Bureau of Labor Statistics om de twee jaren een prognose van de arbeidsmarktontwikkeling op de midellange termijn. Daarbij wordt gebruik gemaakt van een systeem waarin een vijftal velden wordt onderscheiden. Zo wordt in de vierde stap de werkgelegenheid per bedrijfstak afgeleid uit prognoses van de macro-economische ontwikkeling door middel van regressie-analyse en trendextrapolatie. Deze resultaten worden in de laatste stap als invoer gebruikt om de beroepenstructuur per bedrijfstak te bepalen. Hierbij vindt de verdeling van de sectorale werkgelegenheid over de beroepen plaats op basis van informatie, die uit bedrijvenenquêtes wordt verkregen. Bij het opstellen van de prognoses vindt er een correctie plaats voor een aantal economische factoren, waaronder de technologische ontwikkeling. In West-Duitsland worden arbeidsmarktprognoses gemaakt in opdracht van het Institut für Arbeitsmarkt- und Berufsforschung (IAB). Ook hier wordt eerst middels een trendmatige extrapolatie de produktie per bedrijfstak afgeleid uit prognoses van de macro-economische

1. Heijke, (1986) en ROA, (1988). 
ontwikkeling. In de volgende stap wordt deze ontleed in produktiviteit en arbeidsplaatsen. De arbeidsplaatsen worden verdeeld over kwalificatiegebieden, die gebaseerd zijn op beroeps- en opleidingskenmerken. Hierbij wordt uitgegaan van de zgn. 'manpower'-benadering.

In de afgelopen jaren zijn er in Nederland verschillende prognoses gemaakt van de werkgelegenheid naar beroep. Zo is in de ANTOS-studie (1984) voor 30 beroepscategorieën onderzocht of er sprake is van een trendmatige ontwikkeling van de werkgelegenheidsaandelen per bedrijfstak. In de NEI-studie (1986) wordt eerst de werkgelegenheid per bedrijfstak bepaald aan de hand van een aantal macro-economische grootheden en vervolgens een prognose per beroep gemaakt op basis van een verdeelmodel waarin een trendterm is opgenomen. Beide onderzoeken hebben echter als nadeel dat de prognoses gebaseerd zijn op tijdreeksonderzoek waar slechts gebruik kon worden gemaakt van een gering aantal waarnemingen. Ook door het ROA (De Grip, Heijke, Dekker en Groot, 1987) is gepoogd middels een verdeelmodel tot een beroepenprognose te komen. Vanwege het geringe aantal waarnemingen moest ook hier de analyse beperkt blijven tot een univariaat verdeelmodel. De SEO (Teulings, Koopmans, Koopmanschap en Vedder, 1987) heeft dit trachten op te vangen door middel van een model warin de gegevens gepoold worden over de bedrijfstakken en de tijd. Het door de SEO gebruikte model bevat echter ook alleen een trendvariabele. De uitkomsten van een dergelijk trendmodel zijn niet economisch te interpreteren, bovendien veronderstelt een trend noodzakelijkerwijs per beroep in alle bedrijfstakken dezelfde ontwikkelingstendens.

In het beroepenmodel dat in deze studie is ontwikkeld worden de waarnemingen gepoold over de tijd en de bedrijfstakken. Tevens is geprobeerd te komen tot een verklarend model waarmee verschuivingen in de beroepenstructuur van de sectorale werkgelegenheid kunnen worden beschreven. Deze aanpak geeft de mogelijkheid om met een multivariaat model te werken, terwijl bovendien de resultaten beter kunnen worden geĩnterpreteerd dan bij het extrapoleren van de trendmatige ontwikkeling. Er kunnen nu verschillende factoren, die geacht worden de beroepenstructuur te beinvloeden, naast elkaar in het model worden opgenomen. Vanwege de pooling neemt het aantal vrijheidsgraden van de te schatten vergelijkingen toe, hetgeen de nauwkeurigheid van de schattingen ten goede komt.

De opzet van dit rapport is als volgt. Hoofdstuk 2 behandelt het beroepen- 
model, waarbij in de eerste paragraaf van hoofdstuk 2 de uitgangspunten van het model worden beschreven, en in paragraaf 2.2 de economische factoren worden besproken. De bijbehorende variabelen worden gespecificeerd in paragraaf 2.3. In hoofdstuk 3 wordt in paragraaf 3.1 de modelvergelijking afgeleid en in paragraaf 3.2 wordt aangegeven hoe we een keuze maken uit de verschillende varianten van het model. De bespreking van de onderzoeksresultaten vindt plaats in hoofdstuk 4. In paragraaf 4.1 worden de globale resultaten weergegeven, terwijl in paragraaf 4.2 een bespreking per beroepssector plaatsvindt. Tenslotte worden in hoofdstuk 5 de belangrijkste conclusies met betrekking tot het in deze studie gevolgde analysemodel vermeld. 0ok worden enkele suggesties gedaan ten aanzien van de verdere voortzetting van de in deze studie gepresenteerde onderzoekslijn. 


\section{HET BEROEPENMODEL}

\subsection{Inleiding}

Bij de constructie van het model is uitgegaan van de veronderstelling dat de beroepenstructuur in feite door de vraagzijde van de arbeidsmarkt wordt bepaald. In de bedrijfstakken wordt gestreefd naar een optimale functie-, c.q. beroepenstructuur, zodat er op een zo efficiënt mogelijke wijze geproduceerd kan worden. Getracht is deze vraagkant in beeld te brengen door het opstellen van een aantal uit de economische theorievorming af te leiden factoren, die de beroepenstructuur beĩnvioeden.

Als te verklaren variabele is telkens het aandeel van een beroep in een bedrijfstak genomen. De keuze voor het werkgelegen-heidsaandeel is een direct gevolg van de vraagstelling (we willen immers de beroepenstructuur onderzoeken) en de te volgen weg bij de latere prognoses, waarbij wordt gestart vanuit de bedrijfstakprognoses van het CPB (zie ook De Grip, Heijke, Dekker en Groot, 1987). Indien men daarop aansluitend de beroepenaandelen in de bedrijfstakken kan voorspellen, kan hieruit een prognose van de werkgelegenheid per beroep worden gemaakt. Bij de beroepenindeling is uitgegaan van 83 beroepsklassen. De indeling in 24 bedrijfstakken zoals die door het CPB in het CEP ${ }^{2}$ wordt gebruikt vormde het uitgangspunt voor de bedrijfstakindeling, waarbij het aantal onderscheiden bedrijfstakken is teruggebracht tot 21, door de bedrijfstakken voedingsmiddelen (veehouderijprodukten, overige produkten en dranken en tabaksprodukten) samen te voegen, alsmede de bedrijfstakken bouw en woningbezit. De overheid is als aparte 'bedrijfs'sector toegevoegd. Voor een overzicht van de beroepen en de bedrijfstakken wordt verwezen naar de bijlagen 1 en 2 .

\subsection{Mogelijke factoren voor de ontwikkeling van de beroepenstructuur}

In deze paragraaf zullen de factoren, die een verklaring kunnen vormen voor de beroepenstructuur worden besproken, waarna per factor variabelen zullen worden uitgewerkt. De (relatieve) lonen vormen één van de mogelijke oorzaken. Als de loonkosten in een beroepsklasse te hoog worden prijst het beroep zichzelf uit de markt en zal men op zoek gaan naar substituten. Dit

2. Zie bijvoorbeeld het Centraal Economisch Plan 1987, tabel D3 pag. 294. 
kan een organisatorische verandering impliceren, waardoor de desbetreffende beroepscategorie wordt vervangen door een andere beroepsgroep of door een investering in kapitaal. In dit rapport wordt verondersteld dat de loonstructuur zelf niet verandert, of dat de invloed van de loonstructuur constant is. De reden hiervoor is dat goede data met betrekking tot de loonkosten ontbreken. Maar zelfs indien we deze gegevens wel zouden hebben is het de vraag of we loongegevens in deze verkennende fase van de modellering al mee zouden moeten nemen. Het loon is namelijk een endogene factor en vormt zowel een vraag- als aanbodfactor, hetgeen de modelformulering en schatting gecompliceerder maakt.

De aandelen van de beroepen in de overheidssector zijn buiten beschouwing gelaten, omdat de werkgelegenheidsontwikkeling in deze sector zeer specifiek is. Diverse beroepen in deze sector zijn afhankelijk van de financiële ruimte van de overheid en van specifieke demografische ontwikkelingen (aantal jongeren of ouderen). Bovendien zijn er ook problemen in de gegevensverzameling. Het is bijvoorbeeld moeilijk om een beeld te krijgen van de toegevoegde warde of de investeringen van de overheid.

Mede vanwege het feit dat we de aandelen van beroepen in de overheidssector niet schatten, hebben we ook afgezien van de effecten van demografische factoren op de beroepenstructuur. Deze invloed zal met name merkbaar zijn in zeer specifieke beroepen die sterk zijn vertegenwoordigd in de educatieve en verzorgingssfeer. De vraag naar onderwijs of medische verzorging kan veranderen bij een wijzigende bevolkingsstructuur. Men dient dan echter niet alleen een beeld van de bevolkingsstructuur te hebben, maar ook aanvullende gegevens over de intensiteit waarmee een bepaalde bevolkingsgroep gebruik makt van deze diensten. Bovendien zijn voor de beroepen in de verzorgende sfeer reeds studies verricht door het Sociaal en Cultureel Planbureau (CPB/SCP, 1984), terwijl het NEI (1986) de vraag naar leraren heeft onderzocht.

De factoren die invloed kunnen hebben op de beroepenstructuur en in deze studie nader worden onderzocht zijn:

1. Technologische ontwikkelingen.

2. Bedrijfstakgebonden conjuncturele effecten.

3. Bedrijfstakgebonden structurele factoren. 
ad 1. In de literatuur is er geen consensus over de richting waarin de technologie doorwerkt in de beroepenstructuur ${ }^{3}$. Er worden drie stromingen onderscheiden. De eerste gaat uit van een stijging van het aandeel van de specialisten en de leidinggevenden, waarbij ook het aandeel van de beter opgeleiden toeneemt. De oorzaken van deze 'upgrading' zijn dat er nieuwe vaardigheden, meer verantwoordelijkheid, en ook het vermogen om in een veranderende omgeving te werken worden gevraagd. De 'downgrading'-richting benadrukt daarentegen het feit dat de werkzaamheden juist eenvoudiger worden als gevolg van de technologische ontwikkeling. De zojuist genoemde aandelen zullen dan dalen. In de derde visie kennen technologische ontwikkelingen tegengestelde en elkaar opheffende effecten. Het totaaleffect zal afhankelijk zijn van de fase van de technologische ontwikkeling. In de beginfase is er behoefte aan hoger opgeleid personeel (upgrading), terwijl in een later stadium het werk weer een routinematig karakter krijgt (downgrading). Verder zijn ook de omgeving van het bedrijf en de wijze waarop door de bedrijven op veranderingen wordt gereageerd van belang voor de invloed van technologische ontwikkelingen op de beroepenstructuur.

ad 2. De beroepenstructuur kan eveneens beĩnvloed worden door de mate waarin de afzet van een bedrijfstak onderhevig is aan conjuncturele fluctuaties. Als we de arbeidsmarkt opsplitsen in een primair segment, waarin zich de vaste banen, met relatief hoge beloning bevinden, en een secundair segment met tijdelijk werk, slechte arbeidsomstandigheden etc., dan verwachten we de sterkste conjuncturele fluctuaties voor de beroepen op de secundaire markt, die zich kenmerken door een hoge arbeidsmobiliteit (Doeringer en Piore, 1971, De Grip, 1985). Op de primaire arbeidsmarkt zal namelijk vaker sprake zijn van 'labour hoarding' (De Koning, 1987). De bedrijven passen dan hun werkgelegenheid slechts in beperkte mate aan bijeen daling van de afzetmogelijkheden. Redenen hiervoor kunnen zijn: Wettelijke bepalingen, transactiekosten (werving en ontslag), opleidingskosten, reputatie van het bedrijf, technische en organisatorische beperkingen als gevolg van de taakverdeling en overhead arbeid (arbeid die slechts indirect en op een discontinue wijze met de produktieomvang samenhangt), onzekerheid over de afzetmogelijkheden en het imperfect functioneren van de arbeidsmarkt.

3. Voor een overzicht wordt verwezen naar K.I. Spenner, 1985. 
ad 3. Naast conjuncturele fluctuaties kunnen ook structurele ontwikkelingen in een bedrijfstak bepalend zijn voor de beroepenstructuur. Hierbij wordt gedacht aan het verschijnsel dat in kleine bedrijven meer functies in een persoon zijn verenigd. Of aan processen waarbij in een bedrijfstak de kleine bedrijven verdwijnen en alleen grote bedrijven overblijven, of de tendens om werkzaamheden die eerst buiten de bedrijfstak werden verricht, binnen het eigen bedrijf uit te gaan voeren. Voor grote bedrijfstakken zullen er ook eerder beroepsopleidingen worden geinitieerd ${ }^{4}$. 0 ok zien we de opkomst van landen met veel goedkopere arbeidskrachten en de gelijktijdige tendens in Nederland naar kennisintensieve produkten. Dergelijke processen zullen vanwege hun langere-termijn karakter, per bedrijfstak mogelijkerwijs pas met enige vertraging in werkgelegenheidsmutaties tot uiting komen. Men zou dit verloop met behulp van een trendvariabele in kaart kunnen brengen. Toch is verder gezocht naar variabelen die bij deze mogelijke oorzaken kunnen passen omdat de ontwikkeling in de tijd niet voor alle bedrijfstakken dezelfde hoeft te zijn.

\subsection{Specificering van de verklarende variabelen}

Bij de zojuist besproken mogelijke oorzaken zijn variabelen gezocht, die een kwantificeerbare representant vormen voor de desbetreffende factor. Omdat de te verklaren variabele afkomstig is uit de Arbeidskrachtentellingen (AKT) van het CBS, die om de twee jaar zijn gehouden gedurende de periode 19751985, moeten de verklarende variabelen voor deze AKT-waarnemingsjaren in principe bekend zijn op het door ons gebruikte bedrijfstak- en beroepsklasseniveau ${ }^{5}$. Vanwege het feit dat de regressand (het beroepsaandeel) een relatieve grootheid is ligt het voor de hand de regressoren ook in relatieve grootheden uit te drukken, omdat anders de bedrijfstakken warin een bepaalde regressor hoge absolute waarden aanneemt eèn te grote invloed hebben bij de schatting van de parameters.

Om de structurele component van de sectorale ontwikkelingen te kunnen meten zijn twee variabelen geconstrueerd. Deze meten het effect van schaalvergrotingen van de produktie of dienstverlening.

\footnotetext{
4. Den Hartog en Thoolen, CPB, (1971).

5. Enkele uitzonderingen bevestigen de regel: Zie bijlage 2.
} 
$\operatorname{WPGEM}(s, t)=$ Gemiddelde aantal werknemers (per bedrijf) in de

$\operatorname{TWGEM}(s, t)=$ Gemiddelde toegevoegde waarde (per bedrijf) in

de bedrijfstak.

Deze variabelen vertonen echter een breuk in de data. Na 1977 is er een verandering opgetreden in de wijze van meten van het aantal bedrijven, hetgeen het vormen van een consistente tijdreeks bemoeilijkt. Dit hebben we proberen op te vangen door het introduceren van een jaardumy (voor 1975 en 1977). Bij het schatten van de vergelijkingen werden we echter geconfronteerd met multicollineariteit tussen de jaardummy en de bedrijfstakconstanten. Dit heeft ons doen besluiten om deze variabelen niet in de modelvergelijking op te nemen.

Om de structurele component toch in het model te kunnen opnemen introduceren we een trendterm $\tau \quad(=1,2, \ldots, 6)$. Deze variabele meet daarnaast ook de invloed van andere (macro-economische) grootheden, die moeilijk expliciet gemaakt kunnen worden.

De mogelijke oorzaken voor de veranderingen in de beroepenstructuur, die in het model zijn opgenomen zullen nu worden besproken.

De technologische ontwikkeling 'embodied' in fysieke kapitaalgoederen wordt gerepresenteerd door de investeringen in outillage, transport en grond-, weg- en waterbouwkundige werken. Het gat om het structurele effect van de investeringen en we gaan er van uit dat oudere investeringen relatief weinig invloed op de beroepenstructuur hebben. Om het investeringsniveau in het model te kunnen opnemen, is de variabele INVTW geconstrueerd. Deze variabele geeft per bedrijfstak de investeringen weer over de afgelopen 5 jaren ten opzichte van de toegevoegde waarde over de afgelopen 5 jaren.

$\left.\left.\operatorname{INVTW}(s, t)=\sum_{j=-4}^{0} \underset{j}{0} \underset{j=-4}{0} \operatorname{INV}(s, t+j)\right] /[s, t+j)\right]$

$\operatorname{INV}(s, t)=$ investeringen in bedrijfstak $s$ in jaar $t$

$\operatorname{TW}(s, t)=$ toegevoegde waarde.

De mate van automatisering van de produktie c.q. dienstverlening vormt een specifieke karakteristiek van de technologische vernieuwing, die niet vol-

6. Voor de bronvermelding wordt verwezen naar bijlage 2. 
doende in het niveau van de investeringen tot uitdrukking komt. De invloed van automatisering wordt gemeten aan de hand van het aandeel van de automatiseringsdeskundigen in het totaal aantal werkenden binnen een bedrijfstak.

$$
\begin{aligned}
& \operatorname{AUT}(s, t)=\text { Aandeel van de werkzame personen in beroepsklasse } 08 \\
& \text { (= systeemanalisten, statistici, wiskundigen en verwante } \\
& \text { vakspecialisten) in bedrijfstak } s \text { in jaar } t \text {. }
\end{aligned}
$$

Door het opnemen van een beroepenaandeel als regressor zou men moeten overgaan op een simultaan model waarin de beroepenaandelen en het aandeel van de automatiseerders apart beschreven worden. Maar in ons specifiek geval worden de storingstermen tussen de beroepen onafhankelijk verondersteld. Bovendien zijn de exogenen in beide vergelijkingen dezelfde, zodat men de vergelijkingen (de automatiseerders en de andere beroepen) apart met kleinste kwadraten (OLS) kan schatten ${ }^{7}$.

De bedrijfstakspecifieke conjuncturele effecten kunnen het best worden getypeerd door de fluctuaties in de bezettingsgraad in een bedrijfstak. De feitelijke produktie in het desbetreffende jaar wordt dan gerelateerd aan de aanwezige produktie-capaciteit. Deze variabele is echter moeilijk te construeren vanwege de problemen om de capaciteit in een bedrijfstak te bepalen. De oplossing is gezocht in een variabele, die verondersteld wordt rechtevenredig met de bezettingsgraad te fluctueren.

$$
\operatorname{BEZ}(s, t)=\operatorname{TW}(s, t) /\left[(1 / 5) \sum_{j=-2}^{2} \operatorname{TW}(s, t+j)\right]
$$

Het gaat hier om de toegevoegde waarde in het desbetreffende jaar ten opzichte van het 5 -jaarlijkse voortschrijdende gemiddelde van de toegevoegde waarde.

7. Zie Judge et a1., (1982) hoofdstuk 12. 


\section{DE ECONOMETRISCHE MODELLERING}

\subsection{Afleiding van de te schatten vergelijking}

Per beroep wordt een vergelijking opgesteld, waarbij de data gepoold worden over de bedrijfstakken en de tijd. Deze aanpak impliceert de veronderstelling dat de werkgelegenheidsaandelen per beroep, in alle bedrijfstakken waarin dit beroep voorkomt, in dezelfde mate reageren op exogene impulsen. De bedrijfstakken zijn opgedeeld in een tweetal 'hoofdsectoren' te weten de landbouw en industrie enerzijds en de dienstensectoren ${ }^{8}$ anderzijds. Per hoofdsector worden telkens aparte schattingen uitgevoerd. We zouden de pooling ook over alle bedrijfstakken kunnen uitvoeren. Er wordt dan echter aan beide hoofdsectoren eenzelfde structuur opgelegd, in de zin dat de beide hoofdsectoren dezelfde parameters opgelegd krijgen. De schattingen zijn in dit laatste geval weliswaar efficiënter (kleinere varianties van de geschatte parameters), maar indien men feitelijk niet over alle bedrijfstakken had mogen poolen krijgt men te maken met specificatiefouten in het model. Daar het gevaar voor specificatiefouten ernstiger is dan het verlies aan efficiency, is gekozen voor een pooling per hoofdsector. In concreto betekent dit dat de parameters per hoofdsector kunnen verschillen.

In dit rapport is niet voor een kansmode ${ }^{9}$ gekozen. In het lineaire kansmodel tellen de aandelen weliswaar op tot 1 , maar er is geen garantie dat de aandelen zelf tussen 0 en 1 liggen. De probit- en logit-methode vallen af omdat de aandelenmatrix van bedrijfstak naar beroepsklasse voor $75 \%$ bestaat uit nulelementen. Bij pooling van de data bestaat dan de mogelijkheid dat deze elementen groter dan 0 worden geschat. Dit zou betekenen dat we geheel nieuwe (en wellicht irrelevante) beroepen in een bedrijfstak zouden creëren. Schatten van een logitmodel onder nevenrestricties was niet haalbaar vanwege het grote aantal restricties in combinatie met de pooling. Bovendien is het zinvol in dit verkennende onderzoek de mogelijkheid open te houden om na te gaan in hoeverre de restricties bindend zijn. Ook zijn de parameters in onze benadering beter te interpreteren. In het kansmodel dient

8. Voor de verdeling van de bedrijfstakken over de hoofdsectoren wordt verwezen naar bijlage 3 .

9. Zie bijvoorbeeld Judge et al., (1985) hoofdstuk 18. 
men namelijk één beroep als numeraire te kiezen, zodat hiervoor geen uitspraken over de parameterwaarden kunnen worden gedaan.

Naast de kansmodellen, die onder bepaalde veronderstellingen nutsmaximalisatie als economische achtergrond kennen, treft men in vergelijkbare studies met betrekking tot de werkgelegenheid ook wel het zogenaamde verdeelmodel $\operatorname{aan}^{10}$. Het verdeelmodel kent geen economische achtergrond, de specificatie komt op statistische gronden tot stand (aandelen liggen tussen 0 en 1 en tellen op tot 1 ). In een dergelijk model dient men ook een referentie-beroep te kiezen, waardoor de interpretatie van de parameters minder duidelijk is.

Zowel bij de kansmodellen als bij het verdeelmodel impliceert de pooling over de bedrijfstakken en de tijd dat de specificatie voor alle beroepen dezelfde is. In deze studie willen we juist nagaan of deze veronderstelling gewettigd is. Dit leidde tot de keuze voor een multiplicatief model, waarbij wordt uitgegaan van de kleinste kwadraten methode en waar alleen een correctie voor de heteroscedasticiteit plaatsvindt. In de toekomst wordt gepoogd wegen te vinden om de restrictie op de aandelen direct in het model mee te nemen. Ook zal meer nadruk komen te liggen op de opbouw van de storingsterm en kan worden onderzocht of het model verbeterd kan worden indien er van een dynamische benadering wordt uitgegaan.

$$
\begin{aligned}
& Y(b s t)=a(b s) \cdot \prod_{k}\left\{X[k](b s t)^{\beta[k](b)}\right\} \cdot \exp [\tau(b) \cdot t] \cdot P A(b s t) \cdot \exp [\epsilon(b s t)] \\
& b, s, t: \text { Respectievelijk de beroeps-, bedrijfstak- } \\
& \text { en tijdindex. } \\
& Y: \text { : Aandeel van de werkzame personen in het } \\
& \text { beroep in de bedrijfstak t. } 0 . v \text {. het } \\
& \text { bedrijfstak-totaal. } \\
& X \text { : De matrix van verklarende variabelen (excl. } \\
& \text { de trendvariabele). } \\
& t \text { : De trendterm. } \\
& \text { PA : De personen-arbeidsjaren ratio. } \\
& \epsilon \quad \text { : Storingsterm, hiervoor geldt dat deze } \\
& \text { normaal verdeeld is } N(0, \Sigma) \text {, waarbij voor } \Sigma \\
& \text { geldt: } \Sigma=\sigma^{2} \cdot D \text { met } D \text { een diagonaalmatrix: } \\
& \alpha, \beta, \tau \text { : Parameters. }
\end{aligned}
$$


In dit model is de $\beta$-vector te interpreteren als de elasticiteit van $Y$ ten opzichte van $X$ (de elasticiteiten blijuen dus constant). De trendterm wordt exponentieel opgenomen, omdat een interpretatie van een trend $\tau$ als elasticiteit minder geslaagd is. In de bovenstaande specificatie kan de trendparameter gezien worden als een groeivoet. Wel is voorzichtigheid geboden wanneer $\tau$ een hoge waarde heeft, vanwege het gevaar dat het aandeel van een beroep in een bedrijfstak zal 'exploderen'.

De $P / A$-ratio wordt door het CPB gebruikt in de middellange termijnramingen voor de omzetting van arbeidsjaren in werkzame personen ${ }^{11}$. Als indicator voor de P/A-ratio wordt de reciproke van de deeltijdvariabele genomen, waarbij deze laatste als volgt is gedefinieerd.

$\operatorname{DLT}(b, s, t)=\sum_{u}[W P(b, u, t) * W T(u)] / \sum_{u}[W P(s, u, t) * W T(u)]$

$W P(b, u, t)=$ aantal werkzame personen in beroepsklasse $b$ en urenklasse $u$ op tijdstip $t(W P(s, u, t)$ analoog voor de bedrijfstak).

$W T(u)=$ aantal uren (c.q. het midden van de urenklasse). Voor de urenklassen van 40 uur en meer is het klassemidden op 40 uur gezet. Dit laatste is gedaan, omdat iemand die meer dan 40 uur werkt doorgaans toch maar één arbeidsplaats bezet.

Dat het hier om een benadering gaat, schuilt in het feit dat we de normale volledige werktijd in het beroep gelijk stellen aan de normale volledige werktijd in de bedrijfstak (waardoor deze tegen elkaar wegvallen) en in het feit dat we de deeltijd in het beroep in de bedrijfstak vervangen door de deeltijd in het beroep. DLT[bs]/DLT[s] zou in vergelijking 7 gemeten moeten worden, maar bekend is slechts DLT[b]/DLT[s]. De toegepaste benadering is beter naarmate het aantal werkzame personen in beroep $b$ in bedrijfstak $s$, WP[bs], groter is.

Om de parameters te schatten nemen we in vergelijking 6 links en rechts de logaritme en brengen de P/A-variabele naar de linkerkant (en vervangen deze door de DLT-variabele).

$y=a(b s)+\beta(b)^{\prime} \ln \{X(b s t)\}+\tau(b) \cdot t+\varepsilon(b s t)$ 
met

$$
\begin{aligned}
y & =\ln \{Y(\text { bst })\}+\ln \{D L T(\text { bst })\} \\
\beta^{\prime} \ln \{X\} & =\sum_{k} \beta[k] \cdot \ln \{X[k]\} \\
\alpha & =\ln \left(\alpha^{*}\right)
\end{aligned}
$$

Vergelijking 8 wordt geschat met behulp van de gewogen kleinste kwadratenmethode (weighted least squares, WLS), met als gewicht het aantal werkzame personen in het beroep in de bedrijfstak, WP[bs]. De reden hiervoor is dat de regressand een betere benadering voor de populatiewaarden geeft indien meer werkzame personen in een beroep in een bedrijfstak aanwezig zijn; dat wil zeggen de steekproeffout wordt relatief kleiner. Het schatten met WLS heeft daarnaast nog een bijkomend voordeel. De aandelen hebben bijna allemaal waarden die zeer dicht bij 0 liggen. Indien men nu een logaritmische transformatie toepast wordt het bereik van de kleinste aandelen het meest opgerekt. Dit willen we echter voorkomen omdat kleine aandelen (voorzover ze corresponderen met kleine aantallen) minder belangrijk zijn dan grotere aandelen. We willen dus voorkomen dat kleine aantallen werkzame personen de structuur bepalen die ook geldt voor de bedrijfstakken waarin veel werkzame personen zijn vertegenwoordigd.

\subsection{Modelkeuze}

Alleen voor beroepen, die per hoofdsector in twee of meer bedrijfsklassen voorkomen zijn een aantal geneste modellen geschat om na te gaan welke factoren invloed hebben op de beroepenaandelen in de bedrijfstakken. Deze voorwaarde op de data is nodig omdat er anders te weinig waarnemingen zijn voor de multivariate regressie. De aandelen van de beroepen, die niet aan bovenstaande restrictie voldoen zullen op een andere wijze worden bepaald. Dit geldt ook voor de beroepenaandelen in de overheidssector. Men zou deze beroepenaandelen kunnen bepalen middels een univariate regressie, of door het constant houden van het aandeel.

Het geneste model start vanuit een model warin alle verklarende variabelen (de $X$-vector en de trendterm) zijn opgenomen. Dit hebben we het basismodel met trend $(\mathrm{BM}+)$ genoemd. Indien de trendterm significant is wordt voor dit model gekozen. Is dit niet het geval dan vindt er op basis van een F-toets een keuze plaats tussen het model warin de trendterm is weggelaten (alleen de $X$-vector), en het model waarin geen verklarende variabelen zijn opgenomen (noch de $X$-vector, noch de trendterm) en derhalve alleen de bedrijfstakcon- 
stanten overblijven. Deze modellen noemen we respectievelijk het basismodel (BM) en het bedrijfstakdummymodel (SD).

Er wordt dus gestart vanuit het meest uitgebreide model. Indien de trendterm niet significant is wordt deze als eerste uit de modelvergelijking verwijderd, teneinde te voorkomen dat in de voorspellingen een niet-significante trend wordt meegenomen. In de tweede stap wordt dan getoetst of de economische variabelen de fluctuaties in de beroepenaandelen kunnen verklaren. Is dit laatste niet het geval dan wordt voor het bedrijfstakdummymodel, i.e. het gemiddeide over de tijd per bedrijfstak, gekozen.

We willen op deze plaats waarschuwen voor de effecten van de zojuist besproken methode om per beroep een vergelijking te selecteren. In het algemeen gaan dergelijke 'stepwise'-procedures uit van een groot aantal regressoren, die aan de hand van een van te voren gekozen criterium (bv. $R^{2}-$ toename) al dan niet in het model worden opgenomen. Ingeval van multicollineariteit kan dit ertoe leiden dat de 'verkeerde' variabelen in de regressie-vergelijking worden opgenomen, omdat de effecten niet eenduidig aan de variabelen zijn toe te wijzen. Bij gebruik van een stepwise-methode wordt de economische relevantie van de verklarende variabelen losgelaten. Men laat in feite de keuze van de variabelen aan een procedure, die op nieteconomische gronden te werk gaat. Ook kunnen de resulterende schatters onzuiver zijn en de berekende $t$-waarden hoeven geen $t$-verdeling meer volgen 12. Zo zijn in ons geval de t-waarden voor de exogenen in het basismodel conditioneel op de eerste toets (test op de trendterm). Wil men hiervoor corrigeren dan komt men in complexe statistische theorie terecht, wat een op zichzelf staand onderwerp is. Daarom zien we er van af om voor deze effecten te corrigeren, maar nemen deze kennis wel mee naar het volgende hoofdstuk waar de regressie-uitkomsten worden geanalyseerd.

De gecorreleerdheid tussen de regressoren heeft ook tot gevolg dat de parameters niet alleen het effect van de bijbehorende variabele aangeven, maar ook een deel van de invloed van de andere (gecorreleerde) regressoren opneemt. Als men wil toetsen of een bepaalde factor van invloed is op de grootte van de te verklaren variabele kan men in een dergelijke situatie beter het totale effect toetsen (via een F-toets), dan per variabele de $t$ -

12. Zie 0.a. Cassidy, (1981). 
waarde te onderzoeken. Uit bovenstaande blijkt ook dat het gevaarlijk is om alle exogenen met bijvoorbeeld een absolute t-waarde kleiner dan 1 uit het model te verwijderen en de vergelijking vervolgens opnieuw te schatten. 


\section{SCHATTINGSRESULTATEN}

\subsection{Globale resultaten}

De beroepenaandelen zijn voor de twee hoofdsectoren, landbouw \& industrie en tertiaire \& kwartaire diensten, apart geschat. In de sector landbouw en industrie zijn er voor 38 beroepsklassen modelvergelijkingen geschat. Er werd 10 keer voor het basismodel met trendterm (BM+ mode1), 6 keer voor het basismodel (BM model) en 22 keer voor het bedrijfstakdummy-model (SD mode1) gekozen. In de dienstensector zijn 43 beroepsklassen geschat. Hier werd 10 keer het $\mathrm{BM}+, 7$ keer het $\mathrm{BM}$ en 26 keer het SD model geselecteerd. In tabel 1 staat voor de beide hoofdsectoren landbouw \& industrie en de tertiaire \& kwartaire diensten voor elke beroepsklasse de modelkeuze aangegeven, waarbij de beroepen die in beide sectoren voorkomen ook twee keer in de tabel genoemd worden. In totaal waren er 512 beroepenaandelen, die voor schatting in aanmerking kwamen ${ }^{13}$. Vanwege de restrictie dat een beroep per hoofdsector minimal in 2 bedrijfstakken moet voorkomen, vielen 45 beroepenaandelen af, terwijl nog eens 44 aandelen in de overheidssector niet mee werden geschat. In totaal is in deze studie dus $83 \%$ van de beroepenaandelen geanalyseerd.

De algehele tendens is dat de bedrijfstakconstanten veel van de variantie opnemen. Dat blijkt niet alleen uit het aantal malen dat voor het SD model wordt gekozen, maar ook uit de geringe toename van de gecorrigeerde $\mathrm{R}^{2}$ indien voor een ander model wordt gekozen. Bijlage 3 geeft een overzicht van de gecorrigeerde $R^{2}$ van het gekozen model (indien niet het SD model) en van het bijbehorende SD model. In de gevallen dat voor het bedrijfstakdummy model gekozen wordt zijn de beroepsaandelen in de sectorale werkgelegenheid in de loop der tijd stabiel, of de verschillen tussen de bedrijfstakken kunnen niet binnen het huidige model verklaard worden.

In de tabellen 1 tot en met 4 in bijlage 4 worden de resultaten van de uiteindelijk gekozen modellen gepresenteerd. De trendterm neemt in een aantal gevallen een hoge waarde aan. Het meest opvallend is de geschatte trendmatige daling van $20 \%$ voor het toezichthoudend-leidinggevend administratief personeel (beroepscode 30 ). De realisaties van de aandelen

13. In het beroep in de sector werken dan minimaal in 1 jaar meer dan 1000 mensen, of in alle jaren minstens 500 mensen. 
vertonen voor dit beroep een scherpe daling voor de jaren 1981 en 1983, terwijl er voor 1985 weer een hoger aandeel wordt waargenomen. De geschatte aandelen volgen de scherpe daling na 1981 weliswaar niet zo sterk, maar geven wel de omslag na 1983 weer. De feitelijke grote daling in 1981 en 1983 kan wel de oorzaak zijn van de sterke negatieve trend zoals die in het (BM+) model wordt geschat. Het gevaar van een exploderende voorspelling is hier echter niet aanwezig, omdat de trendparameter een negatief teken heeft. In de landbouw en industrie is dit gevaar voor de beroepen statistici, wiskundigen, systeemanalisten e.a. (beroepscode 08 ), beleidvoerende en hogere leidinggevende functies exclusief openbaar bestuur (beroepscode 21) en chemische procesarbeiders e.a. (beroepscode 74) wel aanwezig vanwege de grootte en het positieve teken van de trendterm. In de dienstensectoren geldt dit voor de beroepen statistici, wiskundigen, systeemanalisten e.a. (beroepscode 08), economen (beroepscode 09) en post-distributiepersoneel (beroepscode 37 ). Als we de realisaties en de geschatte aandelen met elkaar vergelijken, dan vinden we bij beroep 09 in één bedrijfstak, en bij beroep 74 in twee bedrijfstakken een situatie die erop duidt dat de trendterm overheerst (of gaat overheersen). Vooralsnog is er voor alle bovengenoemde beroepsklassen geen reden tot ongerustheid met betrekking tot het exploderen van de trendterm, al zal men bij het in de toekomst voorspellen waakzaam moeten blijven voor systematisch te hoog geschatte beroepenaandelen.

De coëfficiënt voor de INVTW-variabele (de investeringen gerelateerd aan de toegevoegde warde) ligt globaal tussen de -1 en +1 . De grootste uitschieters zijn -in de dienstensectoren- het beroep kleermakers, stoffeerders e.a. (beroepscode 79) en het beroep metselaars, timmerlieden e.a. bouwvakarbeiders (code 95). Beroep 79 komt echter slechts in twee bedrijfstakken voor (handel en medisch-veterinair). De reeksen van de INVTW-variabele zijn in beide bedrijfstakken nagenoeg constant, hetgeen het gevaar oplevert van multicollineariteit met de bedrijfstakdumies. Beroep 95 komt zowel in de bovengenoemde twee takken als ook in de andere tertiaire en de andere kwartaire diensten voor. Met name in de andere tertiaire diensten valt eveneens een bijna constant verloop waar te nemen. We dienen hier dan ook erg voorzichtig te zijn met een interpretatie van deze coëfficiënt. Daarnaast moet ook rekening worden gehouden met het feit dat beroep 95 slechts minimal is vertegenwoordigd in de dienstensectoren (maximaal 2.300 op een totaal van 169.000 in het beroep in 1985). De resultaten voor dit beroep in de landbouw en industrie geven geen uitschieters van de geschatte parameters 
te zien. Deze laatste uitkomsten vinden we ook belangrijker, omdat in deze hoofdsector het gros van de werkzame personen is terug te vinden.

De elasticiteit van het werkgelegenheidsaandeel met betrekking tot de bezettingsgraad (BEZ) verschilt sterk tussen de verschillende beroepen. In de landbouw en industrie vertonen de beroepen biologen, biochemici, landbouwkundigen e.a. (code 05 ) en beeldhouwers, kunstschilders, fotografen e.a. creatieve kunstenaars (code 16) op dit punt een erg hoge elasticiteit. In de diensten geldt dit eveneens voor de beroepen statistici, wiskundigen, systeemanalisten e.a. (code 08), toezichthoudend-leidinggevend administratief personeel (code 30) en toezichthoudend-leidinggevend commercieel personeel, inkopers (code 45). Bij de laatste twee leidinggevende beroepsklassen is er duidelijk sprake van 'overhead'-beroepen. In hoofdstuk 2 werd aangegeven dat met name voor dit soort beroepen 'labour hoarding' werd verwacht. Een hoge, significante elasticiteit van de bezettingsgraadvariabele (groter dan 4) wijst echter in een andere richting, namelijk dat deze beroepen zeer gevoelig zijn voor bezettingsgraadfluctuaties. Bij deze confrontatie tussen theorie en uitkomst moet wel nog worden opgemerkt dat alle bovengenoemde beroepen(aandelen) overeenkomen met zeer kleine aantallen werkzame personen in de verschillende bedrijfstakken. Het gevaar van ernstige meetfouten in de endogene variabele is dan niet denkbeeldig. De andere beroepsklassen waar een kleinere elasticiteit van de bezettingsgraad is geschat (en waarvoor de absolute t-waarde groter dan 1 is) geven geen onverwachte tekens te zien.

Een uitschieter voor de automatiseringsvariabele (AUT) is waar te nemen voor het beroep biologen, biochemici, landbouwkundigen e.a. (code 05) in de landbouw en industrie. Deze beroepsklasse komt echter alleen voor in de bedrijfstakken landbouw en de chemische en rubberindustrie. In de landbouw is er bovendien geen significant aandeel van automatiseringspersoneel. Derhalve is AUT voor deze bedrijfstak op 0 gezet. De coëfficiënt heeft bijgevolg alleen betrekking op de chemische en rubberindustrie. Uit de correlatiematrix voor deze bedrijfstak blijkt dat de variabelen INVTW en AUT sterk negatief zijn gecorreleerd $(-.87)$. Het is daarom niet duidelijk of we hier te maken hebben met het automatiseringseffect, of dat deze variabele ook de investeringseffecten of eventueel de trendmatige ontwikkeling meeneemt. Om dit na te gaan zou men extra regressies moeten uitvoeren om de stabiliteit van de automatiseringsparameter na te gaan. Het voert echter te ver om dit op deze plaats voor alle parameters en alle beroepen uit te voeren. 
Een beroep dat er wat betreft de verklaarde variantie uitspringt is het toezichthoudend-leidinggevend transport- en communicatiepersoneel (beroep 35 ) in de hoofdsector landbouw \& industrie. In bijlage 4, tabel 1 zien we een gecorrigeerde $R^{2}$ van 0,06 . Het beroep komt voor in de bedrijfstakken voeding, papiergrafische industrie en de chemische en rubberindustrie. Het feit dat de verklarende modellen geen verklaring vormen voor het verloop van de aandelen duidt erop dat de door ons gekozen factoren geen verklaring zijn voor het verloop van de te verklaren variabele. Ook het gebruik van het bedrijfstakdumy model geeft amper verbetering. Dit zou er op kunnen duiden dat we niet over de bedrijfstakken hadden mogen poolen, of dat er sprake is van niet in de analyse opgenomen factoren, die van invloed zijn op de structuur van beroep 35 .

Afsluitend kan worden gezegd dat de geschatte parameterwaarden nogal uiteenlopen. Men dient echter niet te vergeten dat het hier gaat om een gereduceerde vorm vergelijking, zodat het moeilijk is de invloeden aan een factor toe te rekenen. In een gereduceerde vorm vergelijking vormt de parameter die voor een regressor staat de representatie van meerdere structurele effecten, die dezelfde variabele als indicator hebben. Een duidelijk voorbeeld is de trendparameter, die naast de bedrijfstakgebonden structurele aspecten en de effecten die niet expliciet konden worden onderscheiden, deels ook de technologische ontwikkeling opneemt. Ook hebben we gezien dat de pooling per hoofdsector tot verschillende modelkeuzen per beroep leidt, zodat het niet verstandig lijkt om over alle (dus landbouw en industrie én de tertiaire en kwartaire diensten) bedrijfstakken te poolen.

\subsection{Bespreking van de resultaten op beroepssector niveau}

In deze paragraaf worden de resultaten per beroepssector (1 digit niveau) besproken. We hebben voor deze manier van bespreken gekozen, omdat het tot een overdaad aan informatie zou leiden indien ieder beroep apart behandeld zou worden. Bovendien makt deze aanpak het mogelijk in te gaan op verschillen tussen de beroepsklassen die zich in eenzelfde beroepsector bevinden.

Bij de wetenschappelijke e.a. vakspecialisten, kunstenaars (beroepssector $0 / 1$ ) vinden we belangrijke trendmatige ontwikkelingen voor de beroepen statistici, wiskundigen, systeemanalisten e.a. (beroepscode 08) en economen (code 09). Beroep 08 wordt in de dienstensectoren bestempeld als een over- 
head-beroep (significant negatief teken van de bezettingsgraadvariabele), terwijl de beeldhouwers, kunstschilders, fotografen e.a. (code 16) positief gecorreleerd zijn met de bezettingsgraad. Dit laatste is wellicht terug te voeren op het free-lance karakter van een deel van het werk in deze beroepsklasse, of uitvoering van het werk middels ad hoc opdrachten.

Bij de beleidvoerende en hogere leidinggevende functies (beroepssector 2) komt alleen beroepsklasse 21 in aanmerking voor schatting ${ }^{14}$, omdat beroepsklasse 20 alleen in de overheidssector is vertegenwoordigd. Het teken van de bezettingsgraadvariabele sluit -in de landbouw \& industrie- aan bij het gegeven dat we met een overhead-beroep te maken hebben. Verder is voor deze beroepsklasse in de landbouw en industrie sprake van een sterke stijgende trendmatige ontwikkeling, terwijl de trendterm in de dienstensectoren niet significant is.

Bij de administratieve functies (beroepssector 3 ) kan men de beroepen 30,31 en 35 bestempelen als overhead-beroepen. De andere beroepen in deze beroepssector liggen meer in de uitvoerende sfeer. Derhalve is het vreemd dat voor beroep 30 (toezichthoudend-leidinggevend personeel) een positieve elasticiteit met betrekking tot de bezettingsgraad wordt gevonden. Doorgaans wordt echter voor het SD model gekozen, zodat de conclusie lijkt te zijn dat deze beroepssector een constant aandeel in de diverse bedrijfstakken heeft.

Bij de commerciële beroepen (sector 4) vertonen de verzekeringsagenten, makelaars e.a. (beroepscode 47) en de winkelbedienden e.a. (code 48) in de landbouw en industrie eenzelfde trendmatige ontwikkeling. In deze sector zijn echter slechts schattingen uitgevoerd voor de helft van de voorkomende beroepsklassen. Dit makt het moeilijk om uitspraken over een hele beroepssector te doen. Opvallend is weer de hoge waarde van de bezettingsgraadcoëfficiënt voor een leidinggevend beroep (beroep 45: Toezichthoudendleidinggevend commercieel personeel, inkopers) in de dienstensectoren.

Bij de dienstverlenende functies (sector 5 ) wordt alleen voor de dienstverlenende functies n.e.g. (code 59) in de dienstensectoren een verklarend mo-

14. Zie paragraaf 4.1. Voor beroepsklasse 21 zijn bovendien de waarnemingen uit 1975 niet meegenomen in de analyse, omdat voor dat jaar de waarden voor de aantallen werkzame personen niet erg betrouwbaar zijn, zie ook CBS, AKT 1977 pag. 17. 
del gekozen, terwijl er toch ook in de aandelen van de andere beroepsklassen fluctuaties zijn waar te nemen. Dit kan betekenen dat de pooling binnen de hoofdsectoren landbouw \& industrie en tertiaire \& kwartaire sectoren niet terecht is, of dat er verklarende variabelen zijn, die nog niet in het model zijn opgenomen.

Bij de agrarische beroepen (sector 6 ) is slechts drie maal een regressie uitgevoerd, waarbij telkens voor het bedrijfstakdummy-model werd gekozen. De resterende drie beroepen zijn slechts in één bedrijfstak vertegenwoordigd en derhalve niet geschat.

De beroepssectoren 7, 8 en 9 omvatten de ambacht-, industrie-, transportberoepen en verwante functies. De beroepsklassen waar voor een verklarend model wordt gekozen kennen -op beroep 85 (elektromonteurs e.d) na- een negatieve invloed van de automatiseringsvariabele. Voor alle beroepen met code 8 (op 1 digit niveau) -de zgn. ambachtsberoepen- is een negatieve parameter voor INVTW geschat. Er vindt dus een substitutie van arbeid door kapitaal plaats. Bij de metselaars, timmerlieden e.a. bouwvakarbeiders (beroep 95) zien we een tegengestelde trendmatige ontwikkeling in de beide hoofdsectoren (de bouwsector valt onder landbouw \& industrie). Beroep 98 (chauffeurs, matrozen, treinbestuurders $e_{.} a_{0}$ ) kent in de landbouw en industrie een negatieve invloed van de automatisering. Voor dit beroep geldt echter dat onder deze code, net als een aantal andere beroepencodes in deze bedrijfstak- een aantal 'rest'-beroepen zijn ondergebracht, waardoor de clustering van beroepsgroepen weinig homogene klassen oplevert. Wellicht is dit een verklaring voor het feit dat voor de andere beroepen met code 9 grotendeels het bedrijfstakdummy model wordt geselecteerd.

Uit de schattingsresultaten blijkt dat er geen eenduidig verband te vinden is voor een bepaalde beroepssector. Ook de opdeling van de bedrijfstakken over twee hoofdsectoren brengt geen structuur in de modelkeuzen. Het blijft derhalve moeilijk om tot een generalisatie van de beroepenstructuur te komen. Toch geeft de uitbreiding tot een verklarend model in een groot aantal gevallen een betere verklaring voor het verloop van het werkgelegenheidsaandeel dan het bedrijfstakdummy model, waarin de beroepenaandelen per bedrijfstak constant worden verondersteld. 
Tabel 1. Overzicht van de uiteindelijk gekozen modellen aan de hand van de beroepencodes.

\section{HOOFDSECTOR}

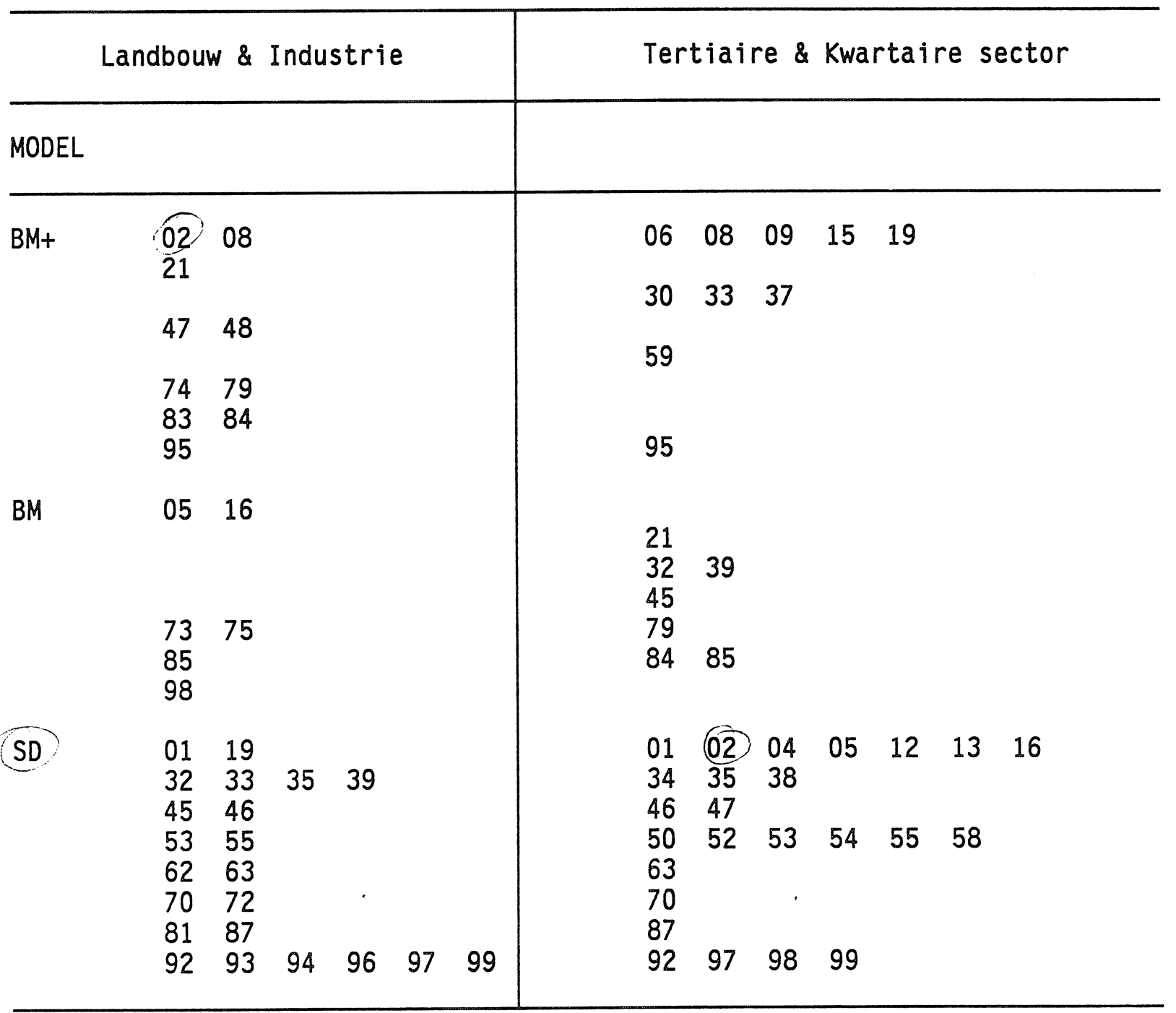

$\mathrm{BM}+=$ Het basismodel met trend dus alle exogene variabelen inclusief de trendterm.

$\mathrm{BM}=$ Het model met alle exogene variabelen exclusief de trendterm.

SD = Het bedrijfstakdummy-mode1. In dit model zijn geen verklarende variabelen opgenomen, maar alleen per bedrijfstak een constante.

In bijlage 1 wordt de koppeling gemaakt tussen de beroepencodes en de benaming van de beroepen zoals die ook door het CBS wordt gehanteerd. 


\section{CONCLUSIES EN SUGGESTIES VOOR VERDER ONDERZOEK}

In deze studie is geprobeerd de ontwikkeling van het werkgelegenheidsaandeel van de beroepsklassen in de verschillende bedrijfstakken te verklaren vanuit een model waarin naast een trendterm ook verklarende economische variabelen zijn opgenomen. Er is een aantal factoren genoemd die de beroepenstructuur kunnen beinvloeden. Daarvan zijn uiteindelijk de technologische ontwikkeling en de bedrijfstakgebonden conjuncturele en structurele effecten in het model opgenomen.

Het doel van deze studie was om de oorzaken van de ontwikkeling van de beroepenstructuur te onderzoeken. Daarbij is gebruikt gemaakt van pooling van de waarnemingen over de tijd en de bedrijfstakken. Dit impliceert dat verondersteld wordt dat de reacties van een beroep op exogene veranderingen in de verschillende bedrijfstakken eenzelfde effect hebben, hetgeen echter niet wil zeggen dat de effecten in de bedrijfstakken of de tijd hetzelfde zijn. In $40 \%$ van de uitgevoerde schattingen is gekozen voor een verklarend model. Een dergelijk model verdient de voorkeur boven het constant houden van de beroepenaandelen of het opleggen van een louter trendmatige ontwikkeling. Op deze wijze wordt namelijk een groter inzicht verkregen in de processen die bepalend zijn voor de relatieve werkgelegenheid in een bepaald beroep, al dient men er rekening mee te houden dat het hier gaat om een gereduceerde vorm vergelijking.

Het model dat is ontwikkeld kent beperkingen met betrekking tot het gebruik van bepaalde dataverzamelingen, waardoor in het uiteindelijke model minder verklarende factoren konden worden getoetst dan aanvankelijk de bedoeling was. In de toekomst zou meer aandacht kunnen worden geschonken aan de kwaliteit van de verklarende variabelen. Zo is de benadering voor de deeltijdfactor voor verbetering vatbaar. Ook kan er nog gezocht worden naar een andere investeringsvariabele teneinde het gevaar van multicollineariteit met de trendterm of de bedrijfstakconstante te verminderen. De indruk bestaat dat dit verschijnsel in een aantal schattingen van invloed is geweest. Voor het prognosticeren van de aandelen is dit overigens niet gevaarlijk (zolang de samenhang tussen de toekomstige waarden van de regressoren zich voortzet), maar het belemmert wel de interpretatie van de parameters. 
De econometrische modellering van de ontwikkeling van de verdeling van de sectorale werkgelegenheid naar beroepen bevindt zich nog in een beginstadium. $\mathrm{Er}$ is in dit rapport uitgegaan van een model met constante elasticiteiten, waarin nog geen rekening wordt gehouden met het feit dat we te maken hebben met aandelen die optellen tot 1 . Enerzijds is dit bewust gebeurt. We willen later bij het opstellen van de prognoses nagaan in welke mate de restricties (per bedrijfstak) bindend zijn. Bovendien zou het construeren en toepassen van een methodiek die rekening houdt met deze restricties te veel tijd in beslag nemen. Gestreefd wordt te komen tot een modellering waarin de restricties in de schattingsprocedure zijn opgenomen en warin de parameters tevens duidelijk interpreteerbaar zijn. 


\section{$\underline{\text { LITERATUUR }}$}

Ahamad, B., M. Blaug (eds.), The practice of manpower forecasting; a collection of case studies, Elsevier Scientific Publishing Company, Amsterdam, 1973.

ANTOS, De arbeidsmarkt naar sector, beroep en opleiding, 1983-1988, Verkennende studie van de werkgroep Anticiperend Opleidings- en Scholingsbeleid (ANTOS), Ministerie van Sociale Zaken en Werkgelegenheid, Den Haag, 1984.

Bos, W., Overeengekomen jaarlijkse arbeidsduur, jaargemiddelde aantal banen en arbeidsvolume van werknemers, 1977-1986; methode en resultaten van een proefonderzoek, CBS Supplement bij de Sociaal-Economische Maandstatistiek, CBS, Voorburg, jaargang 1987 no. 5, pp. 9-20.

Broeder, G. den, J. de Voogd, De arbeidsmarkt van leerkrachten in het voortgezet onderwijs - Paper ten behoeve van de Onderwijsresearchdagen 1986, Nederlands Economisch Instituut, Rotterdam, 1986.

Bureau of Labor Statistics, Employment Projections for 1995, U.S. Department of Labor, Bureau of Labor Statistics, Bulletin 2197, Washington, 1984.

Cassidy, H.J., Using Econometrics: A Beginner's Guide, Reston Publishing Company Inc. (A Prentice-Hal1 Company), Reston, 1981.

Centraal Bureau voor de Statistiek, Arbeidskrachtentellingen, CBS, Voorburg, $1975,1977,1979,1981,1983,1985$.

Centraal Planbureau, Centraal Economisch Plan 1987, CPB, 's-Gravenhage, 1987.

Centraal Planbureau en Sociaal en Cultureel Planbureau, Arbeidsvraag en -aanbod in de gezondheidszorg op de lange termijn, Centraal Planbureau, PKS-bulletin no. 5, 's-Gravenhage, 1984.

Doeringer, P.B., M.J. Piore, Internal Labor Markets and Manpower analysis, Heath Lexington Books, Lexington, 1971.

Grip, A. de, Interne arbeidsmarkttheorieën: Een overzicht, in: Maandschrift Economie, 1985, pp. 333-345.

Grip, A. de, J.A.M. Heijke, R.J.P. Dekker, L.F.M. Groot (ROA), De arbeidsmarkt naar beroep in 1992 en de positie van academici daarbinnen, Researchcentrum voor Onderwijs en Arbeidsmarkt, ROA-W-1987/1, Maastricht, 1987.

Hartog, H. den, B.A. Thoolen, Requirements and Supply of Qualified Manpower: Projections for the Netherlands (A tentative approach), Central Planning Bureau, Occasional Papers no.2, The Hague, 1971.

Heijke, J.A.M., Het Researchcentrum voor Onderwijs en Arbeidsmarkt, Researchcentrum voor Onderwijs en Arbeidsmarkt, ROA-rapport R-1986/1, Maastricht, 1986.

Hsiao, C., Analysis of panel data, Cambridge University Press, Cambridge, 1986. 
Judge, G.G, R.C. Hill, W.E. Griffiths, H. Lütkepoh1, T.C. Lee, Introduction to the theory and practice of econometrics, Wiley, New York, 1982.

Judge, G.G, W.E. Griffiths, R.C. Hill, H. Lütkepohl, T.C. Lee, The theory and practice of econometrics, Second Edition, Wiley, New York, 1985.

Klauder, W., Der methodische Ansatz des IAB zur längerfristigen Vorausschätzung des Arbeitsmarktes, in: Konzepte der Arbeitsmarkt- und Berufsforschung. Eine Forschungsinventur des IAB, Dieter Mertens, Institut für Arbeitsmarkt- und Berufsforschung der Bundesanstalt für Arbeit, Beitrag BeitrAB 70, Nürnberg, 1984, pp. 173-181.

Koning, J. de, Omvang en oorzaken van labour hoarding, Nederlands Economisch Instituut, Rotterdam, 1987.

Leser, L.E.V., Family Budget Data and Price-Elasticities of Demand, Review of Economic Studies, Vo1. IX, 1941-1942, pp. 40-57.

NEI, Een verkenning van de arbeidsmarkt naar beroep en opleiding tot 1990, Organisatie voor Strategisch Arbeidsmarktonderzoek, OSA-Werkdocument nr. W17, Zoetermeer, 1986.

ROA, Naar een informatiesysteem onderwijs-arbeidsmarkt, onderzoeksprogramma 1988/1989, Researchcentrum voor Onderwijs en Arbeidsmarkt, ROA-rapport R-1988/1, Maastricht, 1988.

Spenner, K.I., The upgrading and downgrading of occupations, Review of Educational Research, vol. 55, no. 2, pp. 125-154, 1985.

Teulings, C.N, C.C. Koopmans, M.A. Koopmanschap, L. Vedder (SEO), Herverdeling van arbeid en Sociale Zekerheid, Ministerie van Sociale Zaken en Werkgelegenheid, Commissie Onderzoek Sociale Zekerheid, Cosz-reeks nr. 13, Den Haag, 1987. 
BIJLAGE I : OVERZICHT VAN DE BEROEPENCODES EN DE BIJBEHORENDE BENAMING

BIJLAGE II : BEDRIJFSTAKINDELING EN BRONVERMELDING VAN DE VARIABELEN

BIJLAGEN III : VERSCHILLEN TUSSEN GECORRIGEERDE $R^{2}$ VOOR HET GEKOZEN MODEL EN HET BEDRIJFSTAKDUMMY MODEL

BIJLAGEN IV : SCHATTINGSRESULTATEN 
BIJLAGE I: OVERZICHT VAN DE BEROEPENCODES EN DE BIJBEHORENDE BENAMING CODE BEROEPSKLASSE

01 Schei-, natuurkundigen en verwante technici.

02/03 Architecten, ingenieurs en verwante tecnici, tekenaars.

04 Vliegtuig- en scheepsofficieren.

05 Biologen, biochemici, landbouwkundigen en verw. spec.

06/07 Genees- en tandheelkundigen, dierenartsen, verplegenden en verwante vakspecialisten.

- 08 Statistici, wiskundigen, systeemanalisten en verwante vakspecialisten.

09 Economen.

- 11 Accountants.

12 Juristen.

13 Leerkrachten.

- 14 Bedienaars van eredienst en verwante functies.

15 Auteurs, jounalisten e.d.

16 Beeldhouwers, kunstschilders, fotografen e.a. creatieve kunstenaars.

17 Musici, toneelspelers e.a. uitvoerende kunstenaars.

18 Beroepssportlieden e.d.

19 Wetenschappelijke e.d. vakspecialisten n.e.g.

20 Beleidvoerende en hogere leidinggevende functies bij openbaar bestuur.

21 Beleidvoerende en hogere leidinggevende functies excl. openbaar bestuur.

30 Toezichthoudend-leidinggevend administratief personeel.

31 Uitvoerende hoofdambtenaren.

32 Secretaressen, typisten, ponstypisten e.d.

33 Boekhouders, kassiers en verwante functies.

34 Boekhoudmachine-, computerapparatuuroperateurs e.d.

35 Toezichthoudend-leidinggevend transport- en communicatiepersoneel.

36 Conducteurs trein, tram, bus e.d. 
37 Post-distributiepersoneel.

38 Telefonisten, telegrafisten e.d.

39 Administratieve functies n.e.g.

40 Directeuren en bedrijfsleiders groothandel.

41 Directeuren en bedrijfsleiders detailhandel.

42 Zelfstandige groothandelaren en tussenpersonen.

43+44 Zelfstandige winkeliers + Zelfstandige detailhandelaren

45 Toezichthoudend-leidinggevend commercieel personeel, inkopers.

46 Vertegenwoordigers, handelsagenten.

47 Verzekeringsagenten, makelaars e.a. tussenpersonen t.b.v. zakelijke diensten, veilinghouders e.d.

48 Winkelbedienden e.a. verkopers (excl. vertegenwoordigers).

49 Commerciële functies $n . e . g$.

50 Directeuren en bedrijfsleiders horecabedrijven.

51 Zelfstandige hote1-, restaurant-, caféhouders e.d.

52 Toezichthoudend-leidinggevend huishoudelijk personeel e.d.

53 Koks, kelners, buffetbediende e.d.

54 Huishoudelijk en verzorgend personeel n.e.g.

55 Huisbewaarders, schoonmaakpersoneel (gebouwen e.d.)

56 Wassers, persers e.d.

57 Kappers, schoonheidsspecialisten e.d.

58 Brandweer-, politiepersoneel, bewakers e.d.

59 Dienstverlenende functies $n . e \cdot g$.

60 Bedrijfsleiders land- en tuinbouw e.d.

61 Zelfstandige land- en tuinbouwers.

62 Agrarische arbeiders.

63 Boswachters en bosarbeiders, griendwerkers e.d.

64 Vissers, jagers e.d.

70 Toezichthoudend-leidinggevend produktiepersoneel. 
71 Mijn-, groeve-arbeiders, bronboorders e.d.

72 Hoogoven-, smeltovenarbeiders, walsers, gieters, vormers e.a. metaalvervaardigende arbeiders.

73 Houtzagers, papiermakers e.d.

74 Chemische procesarbeiders en verwante functies.

75 Spinners, wevers, breiers, ververs en verwante functies.

76 Leerlooiers, pelsbereiders e.d.

77 Voedingsmiddelen- en drankenbereiders.

78 Tabaksbewerkers, tabaksproduktenmakers.

79 Kleermakers, kostuumnaaisters, stoffeerders en verwante functies.

80 Schoenmakers, lederwarenmakers.

81 Meubelmakers e.a. houtbewerkers.

82 Steenhouwers, -zagers, -slijpers e.d.

83 Smeden, gereedschapmakers, machinale metaalbewerkers.

84 Machinebankwerker-monteurs, instrumentmakers, samenstellers en reparateurs van machines en apparaten (excl. elektr.).

85 Elektromonteurs, samenstellers en reparateurs van elektrische apparaten e.d.

86 Radio- en TV-zend-, geluids- beeldapparatuurbedieners.

87 Loodgieters, pijpfitters, lassers, plaat- en constructiewerkers.

88 Goud- en zilversmeden, diamantbewerkers e.d.

89 Glas-, aardewerkvormers en verwante functies.

90 Rubber- en plasticproductenmakers.

91 Papierwaren- en kartonnagewerkers.

92 Drukkers en verwante functies.

93 Schilders.

94 Ambachts- en industrieberoepen n.e.g.

95 Metselaars, timmerlieden e.a. bouwvakarbeiders.

96 Machinisten e.a. bedieners van stationaire machines en installaties. 
97 Laders, lossers, inpakkers, grondwerk-, kraanmachinisten e.d.

98 Chauffeurs, matrozen, treinbestuurders en verwante functies.

99 Arbeiders n.e.g. 
BIJLAGE II: BEDRIJFSTAKINDELING EN BRONVERMELDING VAN DE VARIABELEN

LANDBOUW \& INDUSTRIE

Landbouw, bosbouw en visserij

Voedingsmiddelenindustrie

Textiel-, kleding-, leder- en

schoenindustrie

Hout- en bouwmatrialenindustrie

Chemische en rubberindustrie

Papier- en grafische industrie

Basismetaalindustrie

Metaalprodukten- en optische

industrie

Elektrotechnische industrie

Transportmiddelenindustrie

Aardolie-industrie

Delfstoffenwinning

Openbare nutsbedrijven

\section{TERTIAIRE \& KWARTAIRE DIENSTEN}

Bouwnijverheid en woningbezit

Hande 1

Zee- en luchtvaart

Overige transport- en communicatiebedrijuen

Bank - en verzekeringswezen

Andere tertiaire diensten

Medische en veterinaire diensten

Andere kwartaire diensten

OVERHEID

Overheid
CBS-SBI code

0

20-21

22-24

25,32

26-27

29-31

33

$34,35,38,39$

36

37

28

1

4

5,83

61-66

73,75

$71,72,74,76,77$

81,82

$67,68,84,85,98,99$

93

$91,94-96,97$

90,92 
Bronvermelding van de variabelen.

De definities van de variabelen is in de hoofdtekst terug te vinden. Op deze plaats worden de bronnen aangegeven van de gegevens, die gebruikt zijn om de variabelen te construeren.

\section{REGRESSOREN:}

Bezettingsgraad: De toegevoegde waarde cijfers zijn afkomstig van het CPB. $\mathrm{Er}$ is uitgegaan van de bruto toegevoegde waarde, marktprijzen 1980.

Investeringen: De investeringscijfers zijn verkregen bij het $C P B$ en betreffen de investeringen in grond-, weg- en waterbouwkundige werken, outillage en transportmiddelen in prijzen van 1980. Voor de bedrijfstakken banken \& verzekeringen, andere tertiaire diensten, medische en veterinaire diensten en de andere kwartaire diensten waren geen aparte investeringscijfers bekend. Van het totaal van deze vier bedrijfstakken is daarom aan iedere bedrijfstak een evenredig deel (1/4e) toegekend.

Automatisering: Voor bedrijfstakken met geen significant aandeel van beroepsklasse 08 is deze variabele in de uiteindelijke vergelijking 8 ) op 0 gezet.

Aantal bedrijven: Dit cijfer is voor 1975 en 1977 gebaseerd op de Sociale Maandstatistiek van het CBS. In 1978 werd overgeschakeld op een andere methodiek waardoor de reeks een breuk vertoont. Uiteindelijk zijn deze gegevens niet meegenomen in de schattingen.

\section{REGRESSAND:}

De beroepenaandelen en de deeltijdfactor (gemiddelde werktijd per beroepsklasse en per bedrijfstak) zijn afgeleid uit de Arbeidskrachtentellingen van net CBS. 
BIJLAGE III: OVERZICHT VAN DE GECORRIGEERDE $R^{2}$ VAN HET GEKOZEN VERSUS HET BEDRIJFSTAKDUMMY-MODEL

LANDBOUW \& INDUSTRIE

BEROEPSCODE

02

05

06

08

09

15

16

19

21

30

32

33

37

39

45

47

48

59

73

74

75

79

83

84

85

95

98 $\operatorname{adj} \cdot R^{2}$ adj. $R^{2} S D$

$\begin{array}{ll}.97 & .96 \\ .80 & .55\end{array}$

$.88 \quad .88$

$.70 \quad .38$

$.86 \quad .54$

$.87 \quad .53$

$.94 \quad .93$

$.95 \quad .90$

$.97 \quad .96$

$.97 \quad .93$

$.99 \quad .99$

$.96 \quad .88$

$.98 \quad .98$

$.99 \quad .99$

$.99 \quad .99$

$.96 \quad .96$
TERTIAIRE \& KWARTAIRE DIENSTEN

$\operatorname{adj} \cdot R^{2} \quad \operatorname{adj} \cdot R^{2} S D$

$\begin{array}{ll}.99 & .99 \\ .95 & .84 \\ .82 & .71 \\ .98 & <0 \\ .98 & .98 \\ .85 & .82 \\ .85 & .75 \\ .97 & .96 \\ .99 & .99 \\ .99 & .99 \\ .97 & .95 \\ .99 & .96\end{array}$

$.99 \quad .99$

$.91 \quad .69$

$.97 \quad .95$

$.98 \quad .98$

$.66 \quad .38$ 
BIJLAGE IV: SCHATTINGSRESULTATEN TABEL 1 T/M 4

Tabel 1. Beroepen die in belde hoofdsectoren voorkomen

\begin{tabular}{|c|c|c|c|c|c|c|c|}
\hline \multicolumn{8}{|c|}{ LANDBOUW/INDUSTRIE } \\
\hline $\begin{array}{l}\text { Code } \\
\text { be- } \\
\text { roeps- } \\
\text { klasse }\end{array}$ & $\begin{array}{l}\text { Aantal } \\
\text { sec- } \\
\text { toren }\end{array}$ & $\begin{array}{l}\text { Gekozen } \\
\text { model }\end{array}$ & INVTW & BEZ & AUT & TRND & $\bar{R}^{2}$ \\
\hline 01 & 5 & SD & & & & & .95 \\
\hline 02 & 13 & $B M_{+}$ & $\begin{array}{l}.16236 \\
(1.68)\end{array}$ & $i^{.44231}$ & $\begin{array}{r}-.01303 \\
(.21)\end{array}$ & $\begin{array}{l}.03556 \\
(4.70)\end{array}$ & .97 \\
\hline 05 & 2 & $B M$ & $\begin{array}{r}1.28363 \\
(1.72)\end{array}$ & $\begin{array}{r}4.72950 \\
(1.56)\end{array}$ & $\begin{array}{r}1.31844 \\
(3.09)\end{array}$ & & .80 \\
\hline 08 & 5 & $B M+$ & $\begin{array}{r}-.79608 \\
(1.41)\end{array}$ & $\begin{array}{r}-.72678 \\
(.37)\end{array}$ & --- & $\begin{array}{l}.10209 \\
(2.98)\end{array}$ & .88 \\
\hline 16 & 2 & BM & $\begin{array}{r}-1.69193 \\
(1.72)\end{array}$ & $\begin{array}{r}3.64911 \\
(2.34)\end{array}$ & $\begin{array}{l}14332 \\
(.84)\end{array}$ & & .70 \\
\hline 19 & 3 & SD & & & & & .63 \\
\hline 21 & 13 & $B M+$ & $\begin{array}{r}-.56059 \\
(2.50)\end{array}$ & $\begin{array}{r}-1.58844 \\
(1.73)\end{array}$ & $\begin{array}{r}-.15795 \\
(1.68)\end{array}$ & $\begin{array}{r}.13596 \\
(10.02)\end{array}$ & .86 \\
\hline 32 & 10 & SD & & & & & .70 \\
\hline 33 & 12 & SD & & & & & .93 \\
\hline 35 & 3 & SD & & & & & .06 \\
\hline 39 & 14 & SD & & & & & .94 \\
\hline 45 & 6 & SD & & & & & .80 \\
\hline 46 & 8 & SD & & & & & .92 \\
\hline 47 & 2 & $B M+$ & $\begin{array}{r}1.08823 \\
(2.04)\end{array}$ & $\begin{array}{r}1.48112 \\
(.73)\end{array}$ & $\begin{array}{r}-.28971 \\
(1.69)\end{array}$ & $\begin{array}{l}.08673 \\
(3.93)\end{array}$ & .87 \\
\hline 48 & 7 & $\mathrm{BM}+$ & $i^{.66181}(.90)$ & $\begin{array}{r}-1.75246 \\
(.84)\end{array}$ & $i^{03171}$ & $\begin{array}{l}.08780 \\
(3.15)\end{array}$ & .94 \\
\hline 53 & 5 & SD & & & & & .67 \\
\hline 55 & 7 & SD & & & & & .46 \\
\hline 62 & 3 & SD & & & & & 99 \\
\hline 70 & 11 & SD & & & & & .63 \\
\hline 79 & 3 & $B M+$ & $\begin{array}{r}-.06370 \\
(.31)\end{array}$ & $\begin{array}{r}-.90510 \\
(1.97)\end{array}$ & $\begin{array}{r}-.05013 \\
(.24)\end{array}$ & $\begin{array}{l}.02502 \\
(2.60)\end{array}$ & .99 \\
\hline 84 & 13 & $\mathrm{BM+}$ & $\begin{array}{r}-.21137 \\
(1.57)\end{array}$ & $\begin{array}{r}-.36274 \\
(.78)\end{array}$ & $\begin{array}{r}-.18185 \\
(3.02)\end{array}$ & $\begin{array}{l}.01606 \\
(2.02)\end{array}$ & .98 \\
\hline 85 & 10 & BM & $\begin{array}{r}-.08747 \\
\left(\begin{array}{r}.86)\end{array}\right)\end{array}$ & $\begin{array}{l}.26804 \\
(.57)\end{array}$ & $\begin{array}{l}.15459 \\
(3.07)\end{array}$ & & .99 \\
\hline 87 & 7 & SD & & & & & .98 \\
\hline 92 & 3 & SD & & & & & 99. \\
\hline 95 & 7 & $B M+$ & $\begin{array}{l}.28079 \\
(2.09)\end{array}$ & $\begin{array}{r}1.08272 \\
(1.34)\end{array}$ & $i^{.17254}$ & $\begin{array}{r}-.01657 \\
(2.53)\end{array}$ & 99 \\
\hline 97 & 13 & SD & & & & & .98 \\
\hline 98 & 8 & BM & $\begin{array}{r}-.30049 \\
(1.39)\end{array}$ & $\begin{array}{r}1.04235 \\
(1.24)\end{array}$ & $\begin{array}{r}-.25644 \\
(2.47)\end{array}$ & & .96 \\
\hline 99 & 8 & SD & & & & & .76 \\
\hline
\end{tabular}

Absolute t-waarden tussen haakjes. 
Tabel 2. Beroepen die in beide hoofdsectoren voorkomen

\begin{tabular}{|c|c|c|c|c|c|c|c|}
\hline \multicolumn{8}{|c|}{ TERTIAIR/KWARTAIR } \\
\hline $\begin{array}{l}\text { Code } \\
\text { be- } \\
\text { roeps- } \\
\text { klassen }\end{array}$ & $\begin{array}{l}\text { Aantal } \\
\text { sec- } \\
\text { toren } \\
\end{array}$ & $\begin{array}{l}\text { Gekozen } \\
\text { model }\end{array}$ & ${ }^{n}$ INVTW & BEZ & AUT & TRND & $\bar{R}^{2}$ \\
\hline 01 & 3 & SD & & & & & .78 \\
\hline 02 & 7 & SD & . & & & & .98 \\
\hline 05 & 3 & SD & & & & & .97 \\
\hline 08 & 6 & $B M+$ & $\begin{array}{l}.81324 \\
(1.05)\end{array}$ & $\begin{array}{r}-3.56947 \\
(1.60)\end{array}$ & --- & $\begin{array}{l}.14623 \\
(7.39)\end{array}$ & .95 \\
\hline $\begin{array}{l}16 \\
19\end{array}$ & $\begin{array}{l}3 \\
6\end{array}$ & $\begin{array}{l}\mathrm{SD} \\
\mathrm{BM}+\end{array}$ & $\begin{array}{r}-.17827 \\
(.27)\end{array}$ & $\begin{array}{r}-1.67838 \\
(.72)\end{array}$ & $\begin{array}{r}-.16185 \\
(1.57)\end{array}$ & $\begin{array}{l}.04836 \\
(2.77)\end{array}$ & $\begin{array}{l}.90 \\
.98\end{array}$ \\
\hline 21 & 7 & $B M$ & $\begin{array}{r}-.61460 \\
(.92)\end{array}$ & $i^{.03180}$ & $\begin{array}{l}.33267 \\
(2.67)\end{array}$ & & .85 \\
\hline 32 & 7 & BM & $\begin{array}{l}.66299 \\
(2.48)\end{array}$ & $\begin{array}{r}1.25219 \\
(1.66)\end{array}$ & $\begin{array}{r}-.02016 \\
(.52)\end{array}$ & & .97 \\
\hline 33 & 7 & $\mathrm{BM}+$ & $\begin{array}{r}-.09996 \\
(.42)\end{array}$ & $\begin{array}{l}.62585 \\
(1.12)\end{array}$ & $\begin{array}{r}-.08726 \\
(1.66)\end{array}$ & $\begin{array}{l}.02929 \\
(2.96)\end{array}$ & .99 \\
\hline 35 & 3 & SD & & & & & .98 \\
\hline 39 & 7 & $B M$ & $\begin{array}{l}.53323 \\
(2.75)\end{array}$ & $\begin{array}{r}-.31436 \\
(.50)\end{array}$ & $\begin{array}{r}-.09217 \\
(2.15)\end{array}$ & & .97 \\
\hline 45 & 2 & $B M$ & $\begin{array}{r}-97779 \\
(2.12)\end{array}$ & $\begin{array}{r}4.52699 \\
(4.89)\end{array}$ & $i^{.08421}(.87)$ & & .99 \\
\hline 46 & 2 & SD & & & & & .98 \\
\hline 47 & 3 & SD & & & & & 99 \\
\hline $\begin{array}{l}48 \\
53\end{array}$ & $\begin{array}{l}3 \\
7\end{array}$ & $\begin{array}{l}\text { SD } \\
\text { SD }\end{array}$ & & & & & $\begin{array}{l}.99 \\
.99\end{array}$ \\
\hline 55 & 6 & SD & & & & & .96 \\
\hline 62 & 4 & SD & & & & & .92 \\
\hline 70 & 6 & SD & & & & & .74 \\
\hline 79 & 2 & BM & $\begin{array}{r}5.26445 \\
(5.16)\end{array}$ & $\begin{array}{r}-2.38129 \\
(1.13)\end{array}$ & $\begin{array}{r}-.13323 \\
(.73)\end{array}$ & & .91 \\
\hline 84 & 6 & $B M$ & $\begin{array}{r}-.66297 \\
(1.44)\end{array}$ & $\begin{array}{r}1.45206 \\
(1.10)\end{array}$ & $\begin{array}{r}-.27873 \\
(3.60)\end{array}$ & & .97 \\
\hline 85 & 6 & $B M$ & $\begin{array}{r}-.08356 \\
(.32)\end{array}$ & $\begin{array}{r}.21401 \\
(.20)\end{array}$ & $\begin{array}{l}.14717 \\
(1.64)\end{array}$ & & .98 \\
\hline 87 & 3 & SD & & & & & .86 \\
\hline 92 & 3 & SD & & & & & .67 \\
\hline 95 & 4 & $B M_{+}$ & $\begin{array}{r}5.26997 \\
(3.54)\end{array}$ & $\begin{array}{r}2.54923 \\
(.96)\end{array}$ & $\begin{array}{r}-.00148 \\
(.01)\end{array}$ & $\begin{array}{l}.07950 \\
(2.25)\end{array}$ & .66 \\
\hline 97 & 5 & SD & & & & & .98 \\
\hline 98 & 7 & SD & & & & & 99 \\
\hline 99 & 3 & SD & & & & & .92 \\
\hline
\end{tabular}


Tabel 3. Beroepen die alleen in de landbouw/industrie voorkomen

\begin{tabular}{|c|c|c|c|c|c|c|c|}
\hline $\begin{array}{l}\text { Code } \\
\text { be- } \\
\text { roeps- } \\
\text { klassen }\end{array}$ & $\begin{array}{l}\text { Aantal } \\
\text { sec- } \\
\text { toren }\end{array}$ & $\begin{array}{l}\text { gekoz } \\
\text { model }\end{array}$ & INETW & BEZ & AUT & TRND & $\bar{R}^{2}$ \\
\hline 63 & 3 & SD & & & & & .83 \\
\hline 72 & 3 & SD & & & & & .96 \\
\hline 73 & 2 & $B M$ & $\begin{array}{r}-1.36791 \\
(3.30)\end{array}$ & $\begin{array}{r}-.18870 \\
(.20)\end{array}$ & $\begin{array}{r}-.11594 \\
(1.12)\end{array}$ & & .95 \\
\hline 74 & 4 & $\mathrm{BM+}$ & $\begin{array}{r}-.24316 \\
(1.06)\end{array}$ & $\begin{array}{r}-.99407 \\
(\quad .85)\end{array}$ & $\begin{array}{r}-.51692 \\
(2.03)\end{array}$ & $\begin{array}{r}.11426 \\
(2.66)\end{array}$ & .97 \\
\hline 75 & 2 & $B M$ & $\begin{array}{r}1.72107 \\
(2.19)\end{array}$ & $\begin{array}{r}2.40453 \\
(1.80)\end{array}$ & $\begin{array}{r}-.18600 \\
(.38)\end{array}$ & & .97 \\
\hline 81 & 3 & SD & & & & & .99 \\
\hline 83 & 5 & $\mathrm{BM}+$ & $\begin{array}{r}-.00733 \\
(.03)\end{array}$ & $\begin{array}{r}-.48804 \\
(.77)\end{array}$ & $\begin{array}{r}-.19305 \\
(2.51)\end{array}$ & $\begin{array}{r}-.07647 \\
(7.61)\end{array}$ & .96 \\
\hline 93 & 5 & SD & & & & & .98 \\
\hline 94 & 6 & SD & & & & & .95 \\
\hline 96 & 2 & SD & & & & & .84 \\
\hline
\end{tabular}


Tabel 4. Beroepen die alleen in tertiair/kwartair voorkomen

\begin{tabular}{|c|c|c|c|c|c|c|c|}
\hline $\begin{array}{l}\text { Code } \\
\text { be- } \\
\text { roeps- } \\
\text { klassen }\end{array}$ & $\begin{array}{l}\text { Aantal } \\
\text { sec- } \\
\text { toren } \\
\end{array}$ & $\begin{array}{l}\text { gekozen } \\
\text { model }\end{array}$ & INVTW & BEZ & AUT & TRND & $\bar{R}^{2}$ \\
\hline 04 & 2 & SD & & & & & .99 \\
\hline 06 & 4 & $\mathrm{BM}+$ & $\begin{array}{r}.95851 \\
(.65)\end{array}$ & $\begin{array}{r}.87082 \\
(.22)\end{array}$ & $\begin{array}{r}-.00155 \\
(.02)\end{array}$ & $\begin{array}{l}.04390 \\
(2.23)\end{array}$ & .99 \\
\hline 09 & 4 & $\mathrm{BM}+$ & $\begin{array}{r}.85374 \\
(.53)\end{array}$ & $\begin{array}{r}2.39244 \\
(.71)\end{array}$ & $\begin{array}{r}-.19917 \\
(.58)\end{array}$ & $\begin{array}{l}.15676 \\
(2.74)\end{array}$ & .82 \\
\hline 12 & 3 & SD & & & & & .89 \\
\hline 13 & 4 & SD & & & & & .95 \\
\hline 15 & 2 & $\mathrm{BM}+$ & $\begin{array}{l}.89968 \\
(3.69)\end{array}$ & $\begin{array}{r}1.48523 \\
(.94)\end{array}$ & $\begin{array}{l}.22641 \\
(2.02)\end{array}$ & $\begin{array}{l}.06375 \\
(2.86)\end{array}$ & .98 \\
\hline 30 & 5 & $\mathrm{BM+}$ & $\begin{array}{r}1.90599 \\
(1.50)\end{array}$ & 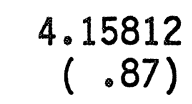 & $\begin{array}{l}.74824 \\
(2.01)\end{array}$ & $\begin{array}{r}-.20398 \\
(3.22)\end{array}$ & .85 \\
\hline 34 & 4 & SD & & & & & .85 \\
\hline 37 & 3 & $\mathrm{BM+}$ & $\begin{array}{r}1.52181 \\
(2.21)\end{array}$ & $\begin{array}{l}.73879 \\
(.76)\end{array}$ & $\begin{array}{r}.05942 \\
(.60)\end{array}$ & $\begin{array}{l}.12225 \\
(2.26)\end{array}$ & .99 \\
\hline 38 & 6 & SD & & & & & .94 \\
\hline 50 & 2 & SD & & & & & .71 \\
\hline 52 & 3 & SD & & & & & .76 \\
\hline 54 & 5 & SD & & & & & .95 \\
\hline 58 & 3 & SD & & & & & .41 \\
\hline 59 & 4 & $\mathrm{BM}+$ & $i^{.40002}$ & $\begin{array}{r}-1.58207 \\
(.58)\end{array}$ & $\begin{array}{r}-.04006 \\
(.73)\end{array}$ & $\begin{array}{r}-.03381 \\
(2.46)\end{array}$ & .99 \\
\hline
\end{tabular}




\section{Rapporten/Reports:}

ROA-R-1986/1 J.A.M. Heijke, Het Researchcentrum voor Onderwijs en Arbeidsmarkt.

ROA-R-1986/1E J.A.M. Heijke, The Research Centre for Education f1 5,-and Labour Market.

ROA-R-1987/1 A. de Grip, J.A.M. Heijke en L.A. Vos, Inventari- niet voor serend onderzoek arbeidsmarktmodule I-SEE project. publicatie

ROA-R-1987/2 Researchcentrum voor Onderwijs en Arbeidsmarkt,
Naar een informatiesysteem onderwijs-arbeidsmarkt, onderzoekprogramma $1987 / 1988$.

ROA-R-1987/3 A. de Grip, J.A.M. Heijke, R.J.P. Dekker, L.F.M. Groot en L.A. Vos, De arbeidsmarktperspectieven van studierichtingen in het wetenschappelijk onderwijs, Arbeidsmarktmodule I-SEE project.

ROA-R-1988/1 Researchcentrum voor Onderwijs en Arbeidsmarkt, Naar een informatiesysteem onderwijs-arbeidsmarkt, onderzoekprogramma $1988 / 1989$.

ROA-R-1988/2 A. de Grip, J.A.M. Heijke, R.J.P. Dekker, en voor L.F.M. Groot, Aanvulling arbeidsmarktmodule I-SEE project (wetenschappelijk onderwijs).

Werkdocumenten/Working Papers:

ROA-W-1987/1 A. de Grip, J.A.M. Heijke, R.J.P. Dekker en L.F.M. Groot, De arbeidsmarkt naar beroep in 1992 en de positie van academici daarbinnen.

ROA-W-1987/1E A. de Grip, J.A.M. Heijke, R.J.P. Dekker en L.F.M. Groot, Labour Market Prospects for Occupations and Academic Studies in 1992.

ROA-W-1987/2E A. de Grip, L.F.M. Groot and J.A.M. Heijke, Clustering Occupational Classes by Educational Structure.

ROA-W-1988/1 A. de Grip, J.A.M. Heijke, Arbeidsmarktindicatoren: f1 12,50 een inventarisatie.

ROA-W-1988/1E A. de Grip, J.A.M. Heijke, Labour Market indicators: f1 12,50 an inventory

ROA-W-1988/2 R.J.P. Dekker, A. de Grip, J.A.M. Heijke, Een f1 $15,--$ verklaring van de beroepenstructuur van bedrijfstakken. 
ROA-W-1988/2E R.J.P. Dekker, A. de Grip, J.A.M. Heijke, An explanation of the occupational structure of branches of industry

ROA-W-1988/3 J.W. van Dam, A. de Grip, J.A.M. Heijke, Op zoek naar informatiebronnen over de arbeidsmarktpositie

f1 17,50 van academici.

Herdrukken/Reprints:

nr. 1 A. de Grip, Causes of Labour Supply and Demand Mismatches f1 $7,--$ $\mathrm{nr}$. 2, 1987, pp. 182-200.

nr. 2 J.A.M. Heijke, The Labour Market Position of Migrants in Selected European Receiving Countries, in: The Future of Migration, OECD, Paris, 1987, pp. 170-209.

nr. 3 J.A.M. Heijke, Internationale migratie en bevolkingsstruc- f1 tuur, in: Demografische veranderingen en economische ontwikkelingen. Preadviezen aan de Koninklijke Vereniging voor de Staathuishoudkunde 1987, 1987, pp. 125-126.

$n r \cdot 4$

A. de Grip, Winnaars en Verliezers op de arbeidsmarkt 1981-1985 in: Tijdschrift voor Arbeidsvraagstukken, jrg. 3, nr. 4, 1987, pp.61-69.

nr. 5 J.A.M. Heijke, Arbeidsmarktinformatie voor studie en beroepskeuze, in: Dekanoloog congresbundel, jrg. 25, $\mathrm{nr} .1$, 1988, pp. 20-22 en 13-14.

nr. 6 J.A.M. Heijke, Arbeidsmarktinformatie en de keuze van studie en beroep, in: Dekanoloog jaarcongres 1988, jrg. 25, $\mathrm{nr}$. 5/6, pp. 155-160.

nr. 7 A. de Grip, J.A.M. Heijke, R.J.P. Dekker, L.F.M. Groot, "De arbeidsmarkt naar beroep in 1992" en "Arbeidsmarktperspectieven van universitaire studierichtingen", in: Economisch Statistische Berichten, 29 juni en 6 juli 1988,73 e jaargang, nrs. 3662 en 3663.

nr. 8 L.F.M. Groot, J.J. Schippers, J.J. Siegers, The effect of interruptions and part-time work on women's wage rate: a test of the variable-intensity model, in: De Economist, $136 \mathrm{nr}$. 2, 1988 pp. 220-238. 